\title{
Dune: Desert Planet
}

Katherine Delay*

Grant MacEwan University, Canada

\begin{abstract}
This article is a review of the science fiction classic Dune, by Frank Herbert, and its environmental message. By designing an entirely new universe for his masterpiece, Herbert enables the reader to draw perspective about the world of $20^{\text {th }}$, and $21^{\text {st }}$, century Earth, and where humanity is possibly headed. Dune, however, is more than just a space opera, it is an enduring message about the struggle between conservation and human avarice.
\end{abstract}

\section{The Book}

Science fiction can be, and often is, a great source of inspiration. One of the first books to inspire me to look at the world through a different lens was Dune. Written by Frank Herbert, a former editor, journalist, and political speechwriter, and published in 1965, Dune is the story of how Paul Atreides, the son and heir of Duke Leto Atreides, comes to rule the harsh desert planet Arrakis, home of the rarest commodity in the universe - the spice Melange. In the feudal universe of the $1100^{\text {th }}$ Century, the ability to exert control over the spice trade is to the Great Houses (noble families) what the oil trade has become to most nations in the $21^{\text {st }}$ century (p. 67).

The book begins on Paul's home-world of Caladan; covered by vast oceans. Caladan is considered a poor planet, as its only export is pundi rice (Herbert, 1965, p. 68). Within the first chapter, the reader learns that Paul's father, the Duke Leto-the ruler of the planet Caladan-will assume control of Arrakis, replacing the Atreides sworn enemies, 
the Harkonnens, a rival House known for its cruelty and wanton abuse of resources ( $\mathrm{p}$. 5). By transitioning the narrative from Caladan to Arrakis; Herbert creates a shift from an all water environment to one that is starkly void of that precious commodity, any moisture; this dialectic provides a clear image of what Earth's future may be, if water continues to be treated as a marketable commodity, and not a right held in common for all.

While it possesses a narcotic effect, the spice is valued most highly by two factions: the Bene Gesserit Sisterhood, an order obsessed with preserving the best of humanity and maintaining political balance (Herbert, 1965, pp.18-19), and the Spacing Guild, a sect of beings who through long use of the spice are no longer truly human, and who possess a total monopoly on all interstellar travel. The Bene Gesserit used the spice to extend their perceptions, allowing them to look into the future, the past, and the present, via accessing a form of genetic memory. As well, the spice grants the strongest of them the ability to see the truth of what a person is saying-a useful ability in political situations (p. 19). For the Navigators of the Spacing Guild, the spice Melange grants a limited precognition, which enables the user the ability to see a clear path through space and time- without this ability, interstellar travel could not exist (p. 828). For users of the noble houses, who can afford it, the spice has life-enhancing properties; it allows for greater health and vitality, granting the user the capacity to live for hundreds of years (pp. 103, 169, 848).

It is also a highly addictive substance that has been the justification of many interHouse wars and assassinations, including the one that kills Paul's father, and sends Paul and his mother, the concubine-lady Jessica fleeing into the deep desert - and to the Fremen, the wild people of the desert (pp. 256-435). With the interplay between these three factions, a parallel is easily drawn to the many international conflicts over oil in the past century; as well as what might be in store for humanity in the next century in regards to the control of water.

Through a dazzling array of characters, plots, sub-plots, machinations, and maneuvers, Dune questions the nature of power, religion, government, drug addiction, and corruption. But Dune is more than just a mélee of Machiavellian intricacies and human fallacies.

It is about nature and environmental balance. It is also a reflection on how natural resources, specifically water, are commoditized and devalued by those with wealth and power. For example: on Arrakis, water is constantly in short supply (Herbert, 1965, p. 101) and in high demand, and the polar ice caps are mined for it (p. 98). To waste water 
is considered an act of great foolishness, and it is an act that those who are rich enough display. The Harkonnens, for example, used water as a weapon to demoralize and dehumanize those under their power:

Beside each plate on the long table stood a flagon of water. There was enough water along the table, the Duke estimated, to keep a poor Arrakeen family for more than a year.

Flanking the doorway in which he stood were broad laving basins of ornate yellow and green tile. Each basin had its rack of towels. It was the custom, the housekeeper had explained, for guests as they entered to dip their hands ceremoniously into a basin, slop several cups of water onto the floor, dry their hands on a towel and fling the towel into the growing puddle at the door. After the dinner, beggars gathered outside to get the water squeezings [sic] from the towels. (p. 206)

This waste is contrasted by the frugality of the indigenous people of Arrakis-the Fremen. A people who have adapted to the wilderness around them, they conserve water religiously through whatever means possible, such as recycling their bodily waste (via specially manufactured garments known as stilsuits), storing water in secret underground caches, and reclaiming the water back from their dead for the tribe (Herbert, 1965, p. 222). All are sustainable practices ingrained and integrated into their traditions and lifestyles. To the Fremen, the only thing a person possesses is that tribemember's flesh; even the body's water must be returned to the tribe (p. 503). The offering of your body's water, such as shedding tears for the dead (p. 509), is considered the highest honor that can be given to the deceased.

With the continuous parallel between water and spice, wealth and poverty, waste and conservation, Herbert challenges the reader to examine his or her own life and to see the bounty that the reader truly possesses-not just financial wealth. Caladan possesses limitless water and yet is viewed as a poor planet because it lacks much in the way of profitable exports, whereas the rulers of Arrakis possess great monetary wealth, yet dwell in endless sand-seas (Herbert, 1965, p. 68), not to mention the constant fear of thirst and starvation (p. 101). In a world like ours where, to the wealthy, the most valuable resources are not the ones that sustain life but instead are the ones that make it more comfortable for affluent, it is evident how Dune sends a clear statement about the critical issue of water conservation that humans are facing over the next millennium.

One of my favorite quotes from the novel illustrates what I believe is Herbert's underlying belief about the balance of nature and humanity's role in it. "He recalled 
another thing the old woman had said about a world being the sum of many thingsthe people, the dirt, the growing things, the moons, the tides, the suns-the unknown sum called nature...(Herbert, 1965, pp. 51-52)." Humans are not meant to be the sum of the world, only a part of the world. While the Earth is not yet a barren wasteland, Herbert offers us an insight into what the world will become if the acquisition of resources such as oil, metals, gems, and precious minerals is pursued by the wealthy without thought to the consequences for the rest of the world. It is the responsibility of all those in power to consider the impact their choices and desires will have the world over, and remember that humanity and its greed is not the sum of the world, but only a part.

*Writer: Katherine Delay is an International Section Editor with Earth Common Journal, and a first year Bachelor of Communication Studies student, majoring in Professional Communication.

\section{References}

Herbert, F. (1965/2010). Dune. (2010 Edition) New York, NY: Ace 